\title{
The rise of ergativity in Hindi Assessing the role of grammaticalization
}

\author{
Saartje Verbeke \& Ludovic De Cuypere \\ Ghent University
}

This article investigates the origins and development of the ergative patterning in Hindi. Following traditional Indo-Aryan scholarship, two evolutions are discerned: (i) the reanalysis of a passive as an ergative construction, and (ii) the development of an ergative case marker ne. Three different hypotheses have been postulated in the literature to account for the latter change, two of which suggest a grammaticalization path: the first argues for a case marker as a possible source, the second points towards a lexical source. The third hypothesis maintains that language contact is involved in the change. We scrutinize all three hypotheses and conclude that the ne-clitic is borrowed from Old Rajasthani and introduced in analogy to other clitics, which were already in use as reinforcers of existing case functions. We argue furthermore that the rise of the ergative marker can only be adequately explained in relation to the constructional change in (i). Drawing on the traditional account which traces the origins of the ergative construction back to a former passive construction through reanalysis, we argue that it was actually this constructional reanalysis that allowed the introduction of an ergative marker in the language.

Keywords: Indo-Aryan, ergativity, grammaticalization, reanalysis, case

\section{Introduction ${ }^{1}$}

Hindi is one of many languages of the Indo-Aryan language family that display ergativity, a grammatical pattern "in which the subject of an intransitive clause

\footnotetext{
${ }^{1}$ The abbreviations used in this article are the following: ERG: ergative; NOM: nominative; ACC: accusative; OBL: oblique; LOC: locative; DAT: dative; ABL: ablative; INS: instrumental; DEF: definite; M: masculine; F: feminine; sG: singular; PERF: perfect; AUX: auxiliary;
}

Folia Linguistica Historica 30 (2009), 1-24. DOI 10.1515/FLIH.2009.004 ISSN 0165-4004, E-ISSN 1614-7308 @ C Mouton de Gruyter - Societas Linguistica Europea 
is treated in the same way as the object of a transitive clause, and differently from transitive subject" (Dixon 1994: 1). As with most ergative languages, Hindi is split-ergative, which means that the ergative alignment is only found in particular constructions and/or paradigms. In Hindi, the ergative pattern appears in the preterit and perfect tenses. Ergativity is formally marked by the clitic $n e^{2}$ The ergative construction is illustrated in example (1):
(1) maiṃ=ne kìtāb paṛh-ī
I=ERG book.ABS.F.SG read-PERF.F.SG
'I read a book.'

In the present tense, however, an accusative pattern is required, as in (2):
(2) maim laṛki=ko dekh-tā hum
I.NOM girl=ACC See-PRES.M.SG be.AUX.PRES.1SG
'I (m.) see the girl.'

The same accusative pattern is however found in all the tenses (perfect and present) of the historical ancestor of Hindi, the Old Indo-Aryan (OIA) language Sanskrit, as illustrated in (3):
(3) devadatta-h kața-ṃ ca-kär-a
Devadatta-NOM mat-ACC PERF-make-3SG
'Devadatta made a mat.'

Various hypotheses have been proposed for this remarkable shift in grammatical alignment: the change of the accusative alignment of OIA to an ergative alignment in the perfect tenses in the New Indo-Aryan (NIA) Hindi language. It is, however, generally agreed that two basic changes are involved:

(i) The reanalysis of a passive as an ergative construction;

(ii) The development of an ergative clitic ne.

The change in (i) was first postulated in the 19th century (e.g. Schuchardt 1901, Uhlenbeck 1916). A diachronic link between the passive and ergative construc-

P.P.PART: past passive participle; PST: past; CAUS: causative; CP: conjunctive participle. Thanks are due to Peter Hook, Klaas Willems, and an anonymous referee for FoLH.

${ }^{2}$ Following Butt \& King (2004: 170), we use the term 'clitic' to refer to the ergative case markers in Hindi, rather than the more traditional term 'postposition' as used by, for instance, Kellogg (1938), Masica (1990), Blake (1994), Lehmann (2002) and Montaut (2004), amongst others. As Butt \& King point out, a clitic is different from a postposition in that the latter may have a complex form and may be used independently. A clitic, however, is a short case marker and is not free in its distribution. 
tion is indicated by the fact that both constructions share certain formal and semantic features. In many ergative languages, the ergative marker is found to be formally similar to the instrumental marker used in the passive construction. The two constructions also bear semantic resemblances; though the ergative construction suggests a more active reading than the passive.

The ergative construction in Hindi is taken to originate from a former Sanskrit (OIA, 1500-600 BCE) passive construction with a past participle (cf. Pray 1976, Anderson 1978: 371, Comrie 1978: 371, Dik 1978, Estival \& Myhill 1988, Dixon 1994: 190; for another view see Klaiman 1978, Hock 1986 and Hook 1991, treated in section 3). An example of this construction is offered in (4).

(4) devadatt-ena kața-h kr-tah

Devadatta-INs mat-NOM make-NOM.P.P.PART

'The mat is made by Devadatta.'

The second change that is crucial to the shift in alignment is the appearance of the ergative clitic ne (ii). The diachrony of this clitic is still a topic of debate. Drocco (2008) distinguishes three hypotheses that are found in the literature:

a. ne is derived from a former case marker;

b. ne is derived from a lexical element;

c. $n e$ is borrowed from a language where it was used as the dative or accusative marker.

The first hypothesis (a) has recently become popular in the literature on grammaticalization, where the ergative marker is said to be derived from a former instrumental case marker (e.g. Lehmann 2002, 1987, Haspelmath 1998/1990, Heine \& Kuteva's 2002). The second hypothesis (b), which also suggests a grammaticalization path, goes back to the 19th century (Beames 1872). This hypothesis is found in its most recent version in Butt (2001), who argues that the form janiye or janye may have been the source for ne. The third hypothesis (c), originally proposed by Hoernle (1880: 224-5), maintains that ne was borrowed from a neighboring language - possibly Old Rajasthani - where ne or nai was and still is used as the clitic for the accusative/dative case.

In this article we argue in favour of the latter hypothesis and against the hypotheses based on grammaticalization. There are strong arguments against the grammaticalizationist accounts, which allow us to reject these explanations. First of all, it was already pointed out in the 19th century (at least since Beames 1872: 266, 270) that the alleged grammaticalization path from instrumental marker to ergative marker is highly unlikely for Hindi, because the instrumental 
disappeared long before the ergative clitic was introduced; both markers are actually separated by roughly a thousand years. Secondly, we will show that Lehmann's (2002) "grammaticalization channel of cases" cannot be applied to the case of the Hindi ergative clitic. The alleged channel from instrumental to ergative marker can be rejected both on formal and on semantic grounds. The second hypothesis, which relates the ergative marker to a former lexical element, proves to be problematic as well. Although a number of lexical sources have been suggested in the literature, there is no actual data corroborating this hypothesis. Moreover, grammaticalization research indicates that it is unlikely for a lexical element to change to a grammatical case, without first becoming a concrete case (nominative, accusative or related cases).

In contrast to the two hypotheses based on grammaticalization, there are formal as well as semantic arguments that point towards borrowing as a probable explanation for the emergence of the ne clitic in Hindi. The clitic is formally similar to the Old Rajasthani clitics ne/nai. Functionally, these clitics were used to mark dative or accusative case. A change from dative to ergative fits with Lehmann's proposed grammaticalization channels of case and is more likely than a change from a lexical element to an ergative case marker.

Nowadays, syntactic borrowing is often frowned upon as an explanation. But as Harris and Campbell (1995: 120) argue: "Syntactic borrowing is perhaps the most neglected and abused area of syntactic change". So one needs to adduce strong arguments to make a case for syntactic borrowing. In our case, however, there are several arguments that make borrowing a valid hypothesis.

The question remains, however, as to why the ergative clitic came to be used to mark the subject of the transitive sentence in Hindi. We will argue that the ergative clitic arose as a reinforcer (cf. Lehmann 2002: 84) of an already existing ergative construction, in analogy with other clitic markers in Hindi. A number of Indo-Aryan scholars (e.g. Hook 1991, Klaiman 1978 and Hock 1986) maintain that an ergative construction was already present in Hindi before the ergative clitic was used. It is also known that the accusative/dative case in Hindi was already marked by the clitic ko or kaum (cf. Beames 1872: 254). It is therefore likely that the clitic ne was used in analogy with the use of other clitics. So in contrast to the grammaticalizationist accounts, which explains the emergence of the ergative marker independently from the change in construction, we believe that both changes are inherently related, in that the reanalysis of the construction created the necessary premises for overt ergative marking. The reanalysis of the accusative construction to an ergative one created a gap, which allowed for the ergative clitic. 
In the following section we first take a closer look at the three hypotheses that have been put forward for the emergence of the ergative clitic ne. Section 3 discusses the development of the ergative construction before the use of the clitic ne. In section 4 we examine the arguments in favour of grammatical borrowing. Section 5 offers a summary of the article.

\section{The rise of the Hindi ergative clitic ne}

In Hindi, case function, including the ergative, is expressed by means of clitics. Clitics surfaced in Late MIA or early Hindi (cf. Bubenik 1998: 67). They first appeared as syntactic case markers. In example (5) from early Hindi, for instance, the third argument of a ditransitive construction is marked by a clitic, viz. kaum.
(5) rājā bibeka dvārapāla=kauṃ ājñ $-\bar{a}$
karī
king Bibeka guard=DAT order-NOM.F.SG do.PST.F.SG
'King B. ordered the guard.' (lit: 'King B. made the order to the guard.')

In Hindi, two kinds of case markers are used: clitics and postpositions (cf. Butt \& King 2004: 170; Montaut 2004: 60-4 prefers the terminology simple postpositions and complex postpositions). Clitics consist of one short word and generally mark a syntactic case role, such as kaum in (5), which later turns into Hindi $k o$. The clitic is used to mark the direct and indirect object, or the accusative and dative case. The direct case and oblique case are nowadays still distinguished by their respective case marking. The clitics thus add something to the case marking, in that they restrict the interpretation of the syntactic function of the direct or oblique case. Example (6) illustrates this:

The direct case of larke is larka-; bacche is a form of baccha-. -e is the oblique case-ending. Both words take the oblique because they are followed by a clitic and are not in the direct case.

Postpositions are used to mark semantic case roles. They consist of ke followed by an adverb or a noun, for instance ke üpar 'up', ke kāran, 'because of'. These postpositions have a smaller range of use than the case clitics, and they do not replace or add something to the function of the earlier case marking. Their 
origin is a lexical word combined with a form of the genitive ke. They generally appear earlier than the case clitics, for instance upari 'up' was used with an oblique case in Middle Indo-Aryan (cf. De Clercq 2003).

The etymological root of the clitics remains controversial. For many clitics a lexical origin has been suggested. The accusative and dative clitic $k o$, for instance, has been related to the Sanskrit past participle $k r t a$ - 'done' (cf. Montaut 2004: 65), but also to kakùe 'side, armpit' (cf. Beames 1872-1879: 257). The origin of $n e$ is equally uncertain. As mentioned in the introduction, three different hypotheses are found in the literature (cf. Drocco 2008). In the following sections, we discuss each hypothesis successively. We will show that the grammaticalization from instrumental to ergative marker is highly unlikely, that a lexical source is possible but uncorroborated by empirical data, and that borrowing proves to be the most acceptable hypothesis based on the data that is currently available.

\subsection{Hypothesis (a): ne < instrumental case marker}

The Sanskrit instrumental case marker -ena was considered as a possible origin of the Hindi clitic ne in the 19th century (cf. Monier-Williams 1858: 104-5; Trumpp 1872: 113). The same hypothesis remains popular in grammaticalization scholarship. An account of this change is offered by Lehmann, who makes his case by building on his proposed grammaticalization channels of case (cf. Lehmann 2002: 99).

The basic idea underlying Lehmann's grammaticalization channels of cases is that cases may be ranked on a scale of grammaticality. On this view, different cases belong "to the grammar to a greater or lesser degree" (Lehmann 2002: 8). For instance, the ergative case is said to be more grammatical than the instrumental, which, in turn, is more grammatical than, e.g., the comitative case.

Lehmann's putative scale of grammaticality is determined by the relation between the verb and case. Cases determined by the valency of the verb, or grammatical cases, are qualified as being more grammatical than cases that exist independently from the verb, so-called concrete cases (cf. Lehmann 2002: 96).

The two IA cases under investigation, instrumental and ergative, are said to represent two different kinds of case. The instrumental is qualified as a semantic case, the ergative as a grammatical case. In theory, then, the grammaticalization path from instrumental to ergative appears evident: the less grammatical instrumental case grammaticalizes to a more grammatical ergative case (cf. also Heine and Reh 1984 and Haspelmath 1998: 338). The question is, however, whether 
Lehmann's reasoning also applies to the rise of the ergative case in Hindi?

Such a grammaticalization change appears unlikely for two reasons. First, as was already noted by Beames (1872: 267) and Kellogg (1938: 131), the phonological evolution from the Sanskrit case -ena or -ina to ne is improbable in the light of the known sound changes in IA, since /e/ $>/ \mathrm{a} /$ is not attested in the history of IA, and the consonant $/ \mathrm{n} /$ of -ena would have disappeared had the form changed regularly. Secondly, the disappearance of the OIA case marking -ena and the appearance of the NIA ne are no simultaneous phenomena but separated by over ten centuries. A third problem with Lehmann's proposed channels of grammaticalization, which particularly pertains to the case of Hindi, is that Lehmann's analysis fails to account for the case syncretism that is observed in the history of Indo-Aryan.

Old Indo-Aryan has seven cases: nominative, accusative, genitive, dative, ablative, locative, and instrumental case (some nouns have a vocative case as well). In MIA these seven cases merge into three categories. This evolution is outlined in Table 1. The nominative merges with the accusative case into what is traditionally called the direct case. The instrumental merges with the locative into a case here referred to as oblique I. The ablative, genitive and dative merge into a third case, often called oblique II (cf. De Clercq 2003: 2110, Bubenik 1998: 66).

The direct case is generally used to mark the subject of an intransitive sentence. The same case also appears as the case of the object of a transitive verb; the verb then agrees with the object, while the agent is expressed by an instrumental (cf. Bubenik 1998: 142). Because of the case syncretism, it is impossible to analyze the form of the object as a nominative or an accusative. Bubenik (1989: 387) analyzes this stage as the "appearance of the absolutive case", because this case can express the object as well as the subject of an intransitive sen-

Table 1. Case syncretism in MIA

\begin{tabular}{ll}
\hline Old Indo-Aryan & Middle Indo-Aryan \\
\hline Nominative & direct \\
Accusative & \\
Genitive & oblique II \\
Dative & \\
Ablative & \\
Locative & oblique I \\
Instrumental & \\
\hline
\end{tabular}


Table 2. Case syncretism in MIA and NIA

\begin{tabular}{|c|c|c|}
\hline Old Indo-Aryan & Middle Indo-Aryan & New Indo-Aryan \\
\hline $\begin{array}{l}\text { Nominative } \\
\text { Accusative }\end{array}$ & direct & direct \\
\hline $\begin{array}{l}\text { Genitive } \\
\text { Dative }\end{array}$ & oblique II & \\
\hline $\begin{array}{l}\text { Ablative } \\
\text { Locative } \\
\text { Instrumental }\end{array}$ & oblique I & oblique \\
\hline
\end{tabular}

tence. As it is impossible to determine whether the construction is still passive or already ergative, the MIA constructions with this case may be called "semiergative" or "semi-passive" (cf. Bubenik 1989: 389).

In the Early New Indo-Aryan period, case syncretism persists. The Sanskrit case system is ultimately reduced to two cases in Early Hindi, as outlined in Table 2. The two obliques merge into one.

Why is this pattern of case syncretism problematic for the grammaticalization channels of case as proposed by Lehmann? According to Lehmann, case syncretism could only happen between cases of "equal grammaticality" (cf. Lehmann 2002: 99). This implies that it should be impossible for the nominative and the accusative to merge. But this is exactly what happened in NIA.

A fourth and final problem pertains to the alleged grammaticality of the ergative clitic. According to Lehmann, the ergative is a grammatical case. Yet, some uses of the ergative case suggest semantic criteria. In Hindi and other ergative languages certain (anti-impersonal) intransitive verbs (also called "active unergatives", cf. Wali \& Koul 2002) may take an ergative subject. In Hindi, this is the case for verbs such as 'sneezing', 'coughing' (illustrated in ( 7 )), 'urinating' and 'vomiting' (cf. Montaut 2004: 181):

(7) us=ne khās-ā

he $=$ ERG cough-PERF.M.SG

'He coughed.'

In constructions with verbs like in (7), the use of ergative appears to be determined by the semantic notion of 'agent' rather than the verb's valency. ${ }^{3}$

${ }^{3}$ An interesting discussion of the unergative verbs in Hindi is found in Davison (1999). 


\subsection{Hypothesis (b): ne < lexical marker}

The ergative clitic ne has also been related to possible lexical sources. Proponents of this view are Beames (1872: 267), Kellogg (1938: 131), Chatterji (1926: 968) and Butt (2001: 116). Beames (1872: 267) suggests the adjective lāgi or lāgi, 'attached to', as a possible source, which may have evolved to the attested forms $l \bar{a} i$, nai and then le or ne. The form nai is indeed attested in the early literature in Braj, one of the early dialects of Hindi (cf. Bubenik 1989: 382). Chatterji (1926: 968) proposes a form like karnena 'by the ear, side, agency', but it is improbable that this form has evolved to ne. The form takes the instrumental case marking -ena, which could not lead to the form ne (see above). According to Butt (2001: 116), the form janiye or janye may have been the source for ne. A similar clitic is attested in Bengali. How likely is this second hypothesis?

There are two basic problems related to this hypothesis. First, there are no actual attestations of a noun used as an ergative subject and followed by a clitic that is still recognizable as a noun. This either means that there is no lexical source at all, or that there is only a lack of data. Secondly, as research on grammaticalization indicates, it is unlikely that a grammatical case is the direct result of the grammaticalization of a lexical item. It is expected that a lexical item first grammaticalizes into a concrete case, i.e. ablative, locative, allative etc., and only at a second stage into a grammatical case, such as the ergative. However, there are no indications of such an intermediary phase of a concrete case.

\subsection{Hypothesis (c): borrowing}

The third hypothesis that is found in the literature on the diachrony of the ergative marker $n e$ points to language contact. Hoernle (1880: 224-5) already suggested that ne could have been borrowed from the neighboring language Old Rajasthani, where ne or nai was used as accusative/dative clitic from the 15th century onwards (cf. also Kellogg 1938: 132, Khokhlova 2001: 163). ${ }^{4}$ The language

\footnotetext{
${ }^{4}$ An anonymous referee points out that the historical earlier question, i.e. the question of the origin of ne/nai in Old Rajasthani is not taken up in this article. Due to a lack of reliable source material in the native languages from the period before the Indian Middle Ages, it is currently impossible to give a conclusive answer to this question.

The same referee also notes that another possible source language of ne could be Hariyanvi, a language spoken in and around Delhi. Hariyanvi is lexically closely related to Rajasthani, while it is also often considered as a dialect of Hindi. It is a small language with only a limited corpus of literature. A historical sociolinguistic study is required to
} 
was spoken in an area very close to the Hindi area. The following example (8) is an illustration of the early use of nai as an accusative/dative clitic in Old Rajasthani (ex. taken from Khokhlova 2001: 163):
(8) hūm [...]te māthā rājā=nai dekhārsum
I.NOM. that.M.PL. head.M.PL. king=DAT. show.FUT.1SG.
'I shall show these heads to the king.'

In Gujarati and Rajasthani (both coming from the common ancestor Old Rajasthani) $n e$ is nowadays still used as the accusative/dative clitic (cf. Khokhlova 2001: 163). The ergative clitic le and the accusative/dative clitic lai in Nepali also seem to have an origin in the Old Rajasthani language (Kellogg 1938: 132).

If this hypothesis is correct, then an accusative/dative clitic was reused as an ergative clitic. This change is indeed possible on semantic grounds. A semantic similarity between dative and ergative has been pointed out by several authors. Butt (2007) relates the dative and ergative case semantically under the notion of control (cf. also Montaut 2006). She associates the ergative case with control over an action (internal control), while the dative case is associated with goal semantics (external control). Secondly, the ergative and dative case may both be used to mark the transitive subject (cf. dative or "quirky" subjects in Icelandic, Eythórsson 2001), which suggests a semantic similarity. Thirdly, a link between the dative and ergative case is also suggested in Lehmann's grammaticalization channels of case. Lehmann (2002: 97) considers dative as a possible origin of the ergative case according to the grammaticalization channels of case. Although this hypothesis is in the first place conceived for formal cases in the same language, it betrays a possible semantic relation between the ergative and dative case. Clearly, a change from dative to ergative marker is very probable.

\subsection{Intermediate conclusion: the rise of the ergative marker}

So far, we conclude that grammatical borrowing is the most likely hypothesis for the emergence of the Hindi ne. The fact that the clitic had another function in Old Rajasthani, i.e. dative, does not refute the hypothesis.

In itself the source of the clitic does not explain the emergence of the clitic marker as such. It merely shows that the emergence happened. But what exactly

investigate which status Hariyanvi had in the period here considered. As for now, Hariyanvi is considered as one of the many small dialects spoken in the area where Old Rajasthani was the ruling language. 
led the speakers of Hindi to mark the subject of the transitive sentence, considering that in Sanskrit and MIA no ergative marker was used and that this case function is newly introduced in IA languages?

Several authors argue that the construction to which the ne clitic was added, was already ergative before the ergative clitic was introduced. This suggests that the ne clitic functioned as a reinforcer of an existing category rather than as an element that introduced another category into Hindi. We believe, therefore, that in order to understand the emergence of the clitic ne, and to make the case for grammatical borrowing, one needs to look at the construction that was present when the clitic ne arose. As will be explained in the next section, several views on this construction exist in the literature.

\section{The ergative construction ${ }^{5}$}

So far, we have put the emphasis mainly on cases and the changes in functions cases can undergo. However, the rise of ergative marking in Hindi is not only a matter of case. It is not because the agent case eventually receives a reinforced ergative marker that a construction with a perfect or preterit verb, like the one in Hindi, suddenly turns ergative. The decisive factor is the reanalysis of the whole construction, which created the premises for an ergative alignment and which allowed the appearance of an explicitly ergative marker later on.

A crucial construction with regard to the development of ergativity in Hindi is the Past Passive Participle construction. It is this construction that is reanalyzed as an ergative one. The reanalysis of the construction is a condition for the appearance of the ergative marker. It is important therefore to consider the arguments for the claim that the construction was already reanalyzed before the appearance of the ergative marker. A careful analysis of the various stages of Indo-Aryan reveals that the ergative marker does not appear at the same moment when the passive construction gets reanalyzed to an ergative construction.

\subsection{The past passive participle construction}

Old Indo-Aryan is featured by a great complexity of inflectional morphology and an intricate tense system. The past tense, which is important for the diachrony

\footnotetext{
${ }^{5}$ We use the term construction here in a traditional way, viz. denoting a whole consisting of a verb and its arguments, forming a form-meaning unity (cf. van Pottelberge 2007).
} 
of ergativity in Hindi, may be expressed by different verb forms, including a perfect and an imperfect form, an aorist and an analytic construction with a past passive participle. The perfect form is illustrated in the Sanskrit example in (9):

(9) devadatta-h kața-ṃ ca-kār-a

Devadatta-NOM mat-ACC PERF-make-3SG.

'Devadatta made a mat.'

The construction that is most important from our perspective is the past construction with a deverbal past passive participle $-t a$, which is formed by adding the -ta suffix to a verb root. This OIA construction is illustrated in (10):

(10) devadatt-ena kața-h kr-tah

Devadatta-INs mat-NOM make-NOM.P.P.PART.

'The mat is made by Devadatta'

It is generally acknowledged that this past passive construction is the precursor of the ergative construction in Hindi (cf. Harris \& Campbell 1995: 244). The OIA ta-participle is the phonological precursor of the contemporary verb used to mark perfect tense. For instance, the Sanskrit participle krta 'done' becomes

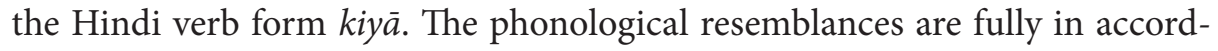
ance with all known Indo-Aryan sound changes. (Pischel 1900).

In OIA the past tense is not formally marked in this construction, which is also why the construction is generally excluded from the OIA tense system (cf. Whitney 1896). In a transitive sentence (cf. 10), the ta-past participle takes a passive sense. The participle additionally requires an instrumental agent, but it agrees with its logical object, similarly to a passive construction; hence it is referred to as past passive participle. In an intransitive construction, the $t a-$ participle has an active meaning and takes a subject in the nominative case. It agrees in gender and number with its subject as is exemplified in (11):

(11) devadatta-h ga-tah

Devadatta-NOM go-NOM.P.P.PART.

'Devadatta has gone.'

The passive voice is not only expressed by means of the past passive participle. There is also a synthetic passive form, which is formed on the basis of the present or past roots. Transitive verbs have a synthetic passive construction with the agent optionally expressed by an instrumental case, as in (12) (taken from Klaiman 1978: 205): 
(12) nar-ena ved-ạh paṭh-ya-nte

man-INS Veda-NOM.PL. recite-PASS-3PL.

'The Vedas are being recited by the man.'

Intransitives are also expressed by means of a passive as in (13) (taken from Klaiman 1978: 205):

(13) t-ena śāy-ya-te

he-INS lie-PASS-3SG.

'There is being laid down by him.' (i.e. 'he lies down.')

\subsection{From OIA past participle construction to Hindi ergative} construction

\subsubsection{The 19th-century approach to ergativity}

When 'exotic' languages were first studied in the 19th century, ergativity was unknown to Western scholars. In an attempt to describe this new phenomenon, ergative languages were initially analyzed in terms of the European accusative systems of grammar. A resemblance between the ergative construction and the European passive construction was soon noticed. Among the first to draw attention to this resemblance are von der Gabelentz (1861), Pott (1873) and Schuchardt (1896). Uhlenbeck (1916), dealing with Amerindian languages, analyzes ergativity as a special kind of passivity.

Early grammars of Hindi (e.g. Kellogg 1938, Beames 1872) offer the same passive interpretation of ergative patterns. In Kellogg's (1938) analysis the ergative case is the case of the 'Agent'. Most importantly, however, Kellogg recognizes that the object of the action is put in the nominative case when used with a "Perfect Participle of Transitive verbs", a construction he calls "Passive construction", which betrays a passive interpretation. Besides the Agent an 'Ablative of agent' is distinguished, the case used to express the agent in the passive voice (cf. Kellogg 1938: 409).

\subsubsection{Diachronic accounts: from passive to ergative}

Contemporary scholarship on ergativity rejects the 19th-century view that ergative languages are accusative languages with a lot of passive constructions (cf. Comrie 1988: 9). Many authors nonetheless acknowledge that ergativity developed out of a passive construction. Particularly the Indo-Aryan languages are said to evidence this evolution (e.g. Pray 1976, Anderson 1978: 371, Comrie 
1978: 371, Dik 1978: 157ff, Estival \& Myhill 1988 and Dixon 1994: 190). Yet the structure that forms the origin of the ergative construction in IA is a participle construction, and thus not a 'true' passive construction. As example (14) illustrates, it is difficult to identify the ta-construction as an unambiguous passive or ergative construction (example taken from Early Middle Indo-Aryan).
(14) iyam dhammalipi
lāj-inā likhāpi-tā
this.NOM true inscription.NOM king-INS write-NOM.CAUS.P.P.PART
'This true inscription was (caused to be) written by the king.'
or: 'The king wrote this true inscription.'

As this construction was more frequently used in later stages of Indo-Aryan, and with the instrumental agent also being expressed more often (cf. Gonda 1951: 107-8), the ta-participle became the norm to express a perfect tense. The example in (15) is taken from a Late Middle Indo-Aryan (600 BCE-100o CE) text. An active interpretation of the sentence appears more obvious than a passive one (cf. Bubenik 1998: 148), which suggests that we are dealing here with an embryonic ergative construction.

(15) laddh-a tuhum maim im-ammmi van-aṃmi find-NOM.P.P.PART YOu.NOM I.OBL this-LOC wood-LOC 'I have found you in this forest.' (lit.: 'You are found in this forest by me.')

Arguments to interpret this construction as passive are the agent which takes an instrumental case, and the agreement with the patient (cf. Anderson 1976). Some authors, in particular Hook (1991), Klaiman (1978) and Hock (1986), argue that the OIA ta-construction should actually itself be regarded as an ergative construction. What are the arguments in favour of this view?

\subsubsection{Ergative remains ergative}

Hook (1991: $178 \mathrm{ff}$ ) points out that the instrumental case takes the subject position in many cases of constructions with the participle (Sanskrit and Hindi are both considered SOV languages). He quotes an example from a text from the 2nd or 3rd century вCE (OIA) (cf. Hook 1991: 178):

(16) na hi pānin-ìna śabd-āh prokt-āh not for Pānini-INS word-NOM.PL. teach-P.P.PART.NOM.PL. 'For it was not words that were taught by Panini.' 
The instrumental case in example (16) is in the first position, which is sometimes considered as the subject position. Sanskrit word order is relatively free, however, so the argument is disputable.

Hook's second argument is that the instrumental case often also serves as the agent of the conjunctive participle (CP) in a sentence. This is illustrated in example (17) (cf. Hook 1991):

(17) tatah śabd-ād abhijñā-ya sa vyaghr-eṇa hat-ah then word-ABL recognize-CP he.NOM tiger-INS kill-NOM 'The tiger recognized him by his voice and killed him.'

The agent of the conjunctive participle vyaghr-ena is here the argument in the instrumental case. The instrumental argument is conceived as the subject actant of the conjunctive participle, and indirectly also as the subject actant of the main verb hatah.

Hook's third and main argument refers to the behaviour of the reflexive pronoun, which at a certain point of time takes the instrumental case as antecedent instead of a nominative phrase.

Based on these arguments, Hook concludes that the ta-construction in Sanskrit turned into an ergative construction very early in its evolution, if it was not ergative from the beginning. The instrumental case functioning as agent is then the oblique subject in a non-nominative case. Formally, the instrumental case does not change in any way when it is used as agent or in a purely instrumental sense. There is thus no proper form of an ergative case, the construction is however of an ergative nature.

The view that Sanskrit already had ergative constructions is most strongly expressed by Klaiman (1978). According to Klaiman (1978: 205), the Sanskrit examples offered in (18) and (19) clearly display an ergative patterning:

nar-ena ved-āh paṭit-āh

man-INS vedas-NOM.M.PL. recite-NOM.M.PL.

'The man read the Vedas.' (or: 'the Vedas were read by the man')

(19) sa śayit-ặ

he.NOM.M.SG. lie-NOM.M.sG.

'He lay down.'

Klaiman's interpretation follows from Dixon's definition of ergativity: the object of the transitive sentence, ved-äh in (18), and the subject of the intransitive sentence, $s a$ in (19), are in the same case and their respective verbs are both in 
agreement. The subject of the transitive verb, nar-ena in (18), however, takes another case marking and does not agree with the verb. Object and intransitive subject are thus treated differently from the transitive subject.

Klaiman's analysis is quite radical from the point of view of Sanskrit philology, which traditionally regards the construction with a past participle as a passive construction. Klaiman's interpretation is based on the agreement between participle and object; this kind of agreement is a feature that determines ergative languages. However, the second feature of ergative languages, the ergative case marking of the subject, is not so prominent. There is no marking of the subject which is labeled as exclusively ergative. The case marking of narena is instrumental in (18). ${ }^{6}$

Klaiman argues further that the ergative construction in NIA could be easily explained by referring to the ergative nature of OIA. Hook (1991), on the other hand, maintains that "their [the past participle's, SV \& LDC] existence in OIA cannot in itself be considered equivalent to the ergativity we find in the New Indo-Aryan languages". In other words, Hook argues for a separate evolution of the past participle and its construction in OIA and of the new ergative construction in NIA. His view is based on the idea that although the ta-construction originally was a passive construction in an accusative language, at a certain point of time a restructuring to an ergative active structure occurred.

Finally, Hock (1986) regards the ta-construction in Sanskrit as "Patientoriented" (see example (11)). In Hock's view, the patient is grammatically focused in Sanskrit, as it is the object which takes the nominative case and agrees with the verb. The oldest forms of Sanskrit, however, would have been subject-oriented, according to Hock. Rather than a change from passive to ergative, Hock suggests a change from patient- to agent-oriented. To Hock, the notion of agent is much more important than that of 'subject' in modern Indo-Aryan languages.

The different interpretations discussed in this section suggest that the difference between the 'passive-to-ergative' approach and the 'ergative remains ergative' approach is a matter of interpretation. We have seen that the passive-to-

\footnotetext{
${ }^{6}$ It might appear as if Klaiman and Hook agreed on the ergative nature of the ta-construction. However, Hook (1991: 188) draws attention to one significant discrepancy between his article and Klaiman's. He argues from a historical comparative viewpoint that it is rather unlikely that the ta-construction was ergative from the very beginning, as the same kind of construction does not lead to an ergative patterning in other IndoEuropean languages, as for instance the to-participle in Greek.
} 
ergative account fails when looking at a detailed chronological description of later evolutions in OIA and MIA, although more extensive research is necessary. The accounts of Klaiman, Hook and Hock differ from each other in details, but mainly they argue for an ergative interpretation of the OIA past participle, which they do not call a passive participle. Their accounts differ from the passive-to-ergative hypothesis in that they situate the change from a passive to ergative construction earlier in the history of the IA languages, even before the evolution to the stage of MIA. According to Hock, the participle had an ergative construction even in PIE. The ergative marker would be a consequence of a reanalysis which happened much earlier than the emergence of the marker.

\subsection{A brief summary}

All the accounts discussed in section 3.2. focused on the construction as such. We conclude that it is a matter of interpretation whether the construction with the ta-participle is analyzed as a passive construction or as an active one. The increasing presence of an instrumental agent is certainly important. We conjecture that a reanalysis of the construction happened at the start of the MIA period (600 BCE). In MIA the past participle is the general means to express a past tense, and the construction looses its marked passive status. In the literary OIA texts of the same age, the past participle is used more often with an instrumental agent, especially in prose texts close to the language of the people (cf. Gonda 1951: 107-8).

The transitive construction with a past 'passive' participle and an instrumental agent became reanalyzed into a transitive perfect construction with a past participle with an active meaning and an ergative agent. A passive construction became used as an active one. The agent remains in the instrumental case, and is not an obligatory part of the sentence. The resemblances with the passive construction are still obvious, as Dik (1978: $161 \mathrm{ff})$ notices. Yet the instrumental agent acquires subject properties, as for instance its function as head when a conjunctive participle appears (Hook 1991: 178).

\section{A case for grammatical borrowing}

If the construction was ergative before the introduction of the ne clitic, then what motivated the speakers of Hindi to borrow an accusative/dative marker 
from the neighboring language Old Rajasthani and to reuse the marker as an ergative clitic in addition to an existing ergative construction? After all, in the earliest phases of Early Hindi, the language functioned perfectly well with a simple oblique for the ergative case (cf. nowadays Balochi). As mentioned already, a case for syntactic borrowing requires strong arguments. Following Dixon (1994: 1), one could argue that an 'ideal' ergative construction asks for an overt ergative marker, and that the ergative clitic was introduced to accommodate this requirement. Similarly, it could also be argued that the ergative marker was necessary to make an overt distinction with other cases. Counterexamples of ergative languages without ergative markers do exist, yet most languages choose an additional (optional) case marking system to distinguish the cases (cf. Dixon 1994: 45). This additional system in Hindi has been created by means of the reinforcement of the case roles. ne is an example of 'reinforcement', a concept defined as the introduction of an adposition combined with an old -degenerated- case affix (cf. Lehmann 2002: 84). ${ }^{7}$ We consider $n e$ as an adposition which reinforced the oblique case marking. It limited the case role of the marked argument to ergative subject, and hence contributed to the diminishing of possible ambiguity between the case roles.

The requirements of case distinction and exclusive ergative marking, however, are not solely responsible for the borrowing of the ergative clitic. As it has been said before, there do exist ergative languages without ergative marking. Another factor is involved in this language change: language contact.

Language contact is defined as the catalyzing factor for borrowing and language change (Harris \& Campbell 1995: 122). There has been language contact between Old Rajasthani and Hindi. The ne/nai clitic has an important role as object marker in Old Rajasthani; it is in fact the only clitic in the language which marks a syntactic case (Khokhlova 2001: 163-7). Extensive language contact drove speakers of Early Hindi to fill the gap of the ergative marker in the ergative construction with this clitic. ${ }^{8}$

\footnotetext{
7 This does not imply that we follow Lehmann's grammaticalization channel of case (cf. Section 2, hypothesis a), which he relates with the concept of reinforcement. The new ergative marker in Hindi does not originate in an adverb which has formerly appeared in the language; in our opinion it was borrowed from a neighboring language.

${ }^{8}$ An anonymous referee reported that Siraiki recently borrowed the ergative case from Punjabi. In this language also, the 'potentiality' for an ergative construction with ergative marker was there; and under influence of a neighboring language, the marker has appeared.
} 


\section{Conclusion}

In this paper we investigated the rise of the ergative patterning in Hindi. We saw that two important changes were at issue: (i) a change from a passive construction to an ergative construction, and (ii) the appearance of an ergative marker ne. First, we investigated three possibilities to explain the origin of the ergative marker (ii) (cf. Section 2). We argued against the grammaticalizationist accounts that relate the ergative marker to either a former instrumental case or a lexical element. Building on Hoernle (1880), we made the case that ne was most likely borrowed from the neighboring language Old Rajasthani, where a formally and semantically similar clitic ne/nai was in use. We argue in addition that the actual introduction of an ergative clitic was made possible by the reanalysis of the passive construction as an ergative. This reanalysis took place earlier than the emergence of the ergative marker, so the construction was already ergative before the appearance of an ergative marker. Finally, we tried to provide an answer to the question why an ergative marker was added to a construction that was already ergative. Two 'traditional' accounts were found wanting, namely the formal requirement that ergativity is ideally marked by means of an overt case marker and case distinction. The account we proposed involves the factor of language contact. This was found to be in line with general claims made for grammatical borrowing.

\section{References}

Aikhenvald, Alexandra Y. 2003. "Mechanisms of change in areal diffusion: new morphology and language contact." Journal of linguistics 39: 1-29.

Anderson, Stephen R. 1976. "On the notion of subject in ergative languages." In: Charles N. Li, ed. Subject and topic. New York: Academic press, 1-25.

Baerman, Matthew \& Dunstan Brown. 2008. "Case Syncretism." In: Martin Haspelmath, Matthew Dryer, David Gil \& Bernard Comrie, eds. The world atlas of language structures online. Munich: Max Planck Digital Library.

Baskararao, P. \& K. V. Subbarao (eds). 2004. Non-nominative subjects. Amsterdam: John Benjamins.

Beames, John. 1872-1879. A comparative grammar of the Modern Aryan languages of India. London: Trubner \& Co.

Blake, Barry J. 1994. Case. Cambridge: Cambridge University Press.

Bubenik, Vit. 1989. "On the origins and elimination of ergativity in Indo-Aryan languages." Canadian journal of linguistics 34: 377-98. 
Bubenik, Vit. 1998. A historical syntax of late Middle Indo-Aryan (Apabhramsa). Amsterdam \& Philadelphia: John Benjamins.

Butt, Miriam. 2001. "A re-examination of the accusative to ergative shift in Indo-Aryan." In: Miriam Butt \& Tracy H. King, eds. Time over matter. Diachronic perspectives on morphosyntax. Stanford: CSLI Publications, 105-42.

Butt, Miriam. 2006a. Theories of case. Cambridge: Cambridge University Press.

Butt, Miriam. 2006b. “The dative-ergative connection.” In: P. Cabredo-Hofherr and O. Bonami, eds. Empirical issues in formal syntax and semantics 6 . The Hague: Thesus, 69-92.

Butt, Miriam \& Tracy H. King. 2004. “The status of case.” In: V. Dayal and A. Mahajan, eds. Clause structure in South Asian languages. Dordrecht: Kluwer Academic Publishers, 153-98.

Chatterji, Suniti. K. 1926. The origin and development of the Bengali language. London: George Allen \& Unwin.

Comrie, Bernard. 1973. "The ergative, variations on a theme." Lingua 32: 239-53.

Comrie, Bernard. 1978. "Ergativity." In: Winfred P. Lehmann, ed. Syntactic typology. Studies in the phenomenology of language. Sussex: The harvester press, 329-93.

Comrie, Bernard. 1984. "Reflections on verb agreement in Hindi and related languages." Linguistics 22: 857-64.

Comrie, Bernard. 1988. "Passive and voice.” In: Shibatani, ed. Passive and voice. Amsterdam: John Benjamins, 9-24.

Davison, Alice. 1999. "Ergativity: Functional and formal issues.” In: Michael Darnell, Edith Moravcsik e.a., eds. Functionalism and formalism in linguistics, Vol. 1. Amsterdam: John Benjamins, 177-208.

De Clercq, Eva. 2003. Een kritische studie van Svayambhudeva's Pammacariu. Gent: Universiteit Gent. Unpublished Ph.D. thesis.

Dik, Simon C. 1978. Functional grammar. Amsterdam: North-Holland Publishing Company.

Dik, Simon C. 1980. Studies in functional grammar. London \& New York: Academic Press.

Dixon, Robert M. W. 1994. Ergativity. Cambridge: Cambridge University Press.

Drocco, Andrea. 2008. L'ergativitā in hindi. Studio diachronico del processo di diffusione della posposizione ne. Alessandria: Edizione dell'Orso.

DuBois, John W. 1987. “The discourse basis of ergativity." Language 63: 805-55.

Estival, Dominique \& John Myhill. 1988. "Formal and functional aspects of the development from passive to ergative systems." In: Shibatani, ed. Passive and voice. Amsterdam: John Benjamins, 441-92.

Eythórsson, Thorhallur. 2001. "Dative vs. Nominative: Changes in quirky subjects in Icelandic." In: Arthur Holmer et al., eds. Proceedings of the 18th Scandinavian Conference of Linguistics, 2. Lund: Lund University, 37-52.

Gabelentz, Hans. C. v. d. 1861. "Ueber das Passivum: Eine sprachvergleichende Abhan- 
dlung." Abhandlungen der Königlich Sächsischen Gesellschaft der Wissenschaften 8: 451-546.

Gonda, Jan. 1951. Remarks on the Sanskrit passive. Leiden: E. J. Brill.

Harris, Alice C. \& Lyle Campbell. 1995. Historical syntax in cross-linguistic perspective. Cambridge: Cambridge University Press.

Haspelmath, Martin. 1990. “The grammaticization of passive morphology." Studies in language 14(1): 25-72.

Haspelmath, Martin. 1998. "Does grammaticalization need reanalysis?” Studies in language 22(2): 315-51.

Heine, Bernd \& Mechthild Reh. 1984. Grammaticalization and reanalysis in African languages. Hamburg: Helmut Buske Verlag.

Heine, Bernd \& Tania Kuteva. 2002. World lexicon of grammaticalization. Cambridge: Cambridge University Press.

Hjelmslev, Louis. 1972 [1935-37]. La catégorie des cas. Munchen: Wilhelm Fink Verlag.

Hock, Hans. H. 1986. "P-oriented constructions in Sanskrit." In: Bhadriraju Krishnamurti. South Asian languages: Structure, convergence and diglossia. Delhi: Motilal Banarsidass, 15-26.

Hoernle, A. F. Rudolf. 1880. A comparative grammar of the Gaudian (Aryo-Indian) languages. Amsterdam: Philo Press.

Hook, Peter. E. 1991. "On identifying the conceptual restructuring of passive as ergative in Indo-Aryan.” In: Madhav M. Deshpande \& Soraja Bhate, eds. Paninian studies. Professor S. D. Joshi felicitation volume. University of Michigan: Center for South and Southeast Asian Studies, 177-200.

Hopper, Paul J. \& Sandra A. Thompson. 1980. "Transitivity in grammar and discourse". In: Language 56 (2): 251-99.

Kellogg, Samuel H. 1938. A grammar of the Hindi language. London: Kegan Paul, Trench, Trubner and Co.

Khokhlova, Liudmilla. V. 1995. "The development of patient-oriented constructions in Late Western NIA languages." Osmania Papers in Linguistics 21: 15-54.

Khokhlova, Liudmilla. V. 2001. "Ergativity attrition in the history of Western New IndoAryan languages." In: Rajendra Singh, ed. The yearbook of South Asian languages and linguistics. New Delhi: Sage Publications, 159-84.

Klaiman, Miriam. H. 1978. "Arguments against a passive origin of the IA ergative." Papers from the annual regional meeting of the Chicago Linguistic Society 14: 204-16.

Langacker, Ronald. 1987. Foundations of cognitive grammar. Stanford: Stanford University Press.

Lehmann, Christian. 2002 [1995]. Thoughts on grammaticalization. Erfurt: Seminar für Sprachwissenschaft der Universität.

Magier, D. 1983. “Components of ergativity in Marwari." In: Papers of the annual regional meeting of the Chicago Linguistic Society 19 (1): 244-55.

Masica, Colin. 1991. The Indo-Aryan languages. Cambridge: Cambridge University Press. 
Monier-Williams, Monier. 1858. Rudiments of Hindustani Grammar. Cheltenham.

Montaut, Annie. 2004. A grammar of Hindi. München: Lincom.

Montaut, Annie. 2006. "The evolution of tense-aspect system in Hindi/Urdu: The status of ergative alignment.” In: Miriam Butt \& Tracy H. King, eds. Proceedings of the LFGo6 Conference. Stanford: CSLI Publications

Peterson, John M. 1998. Grammatical relations in Pali and the emergence of ergativity in Indo-Aryan. München: Lincom Europa.

Pischel, Richard. 1900. Grammatik der Prakrit-Sprachen. Strassburg: Karl J. Trübner.

Pott, A. F. 1873. "Unterschied eines transitiven und intransitiven Nominativs." Beiträge zur vergleichenden sprachforschung auf dem Gebiete der arischen, celtischen und slawischen Sprachen. 7: 71-94.

Pottelberge, Jeroen van. 2007. "Defining grammatical constructions as a linguistic sign: The case of periphrastic progressives in the Germanic languages." Folia Linguistica 41(1-2): 99-134.

Pray, Bruce. R. 1976. "From passive to ergative in Indo-Aryan.” In: Mohanan K. Verma, ed. The notion of subject in South Asian languages. University of Wisconsin-Madison: South Asian Studies, 195-211.

Sapir, Edward. 1917. "Review of Uhlenbeck 1916." International Journal of American linguistics 1(1): 82-6.

Schuchardt, Hugo. 1896. "Ueber den passiven Charakter des Transitivs in den kaukasischen Sprachen." Sitzungsberichte der kaiserlichen Akademie der Wissenschaften 133.

Shibatani, Masayoshi. 1988. Passive and voice. Amsterdam: John Benjamins.

Stump, Gregory. T. 1983. "On the elimination of ergative patterns of case-marking and verbal agreement in modern Indic languages." Ohio State University Working Papers in Linguistics 27: 140-64.

Trumpp, E. 1872. Grammar of the Sindhi language. Osnabrück: Biblio Verlag.

Uhlenbeck, C. C. 1901. "Agens und Patiens im Kasussystem der indogermanischen Sprachen." Indogermanische Forschungen 12: 170-1.

Uhlenbeck, C. C. 1916. "Het passieve karakter van het verbum transitivum of van het verbum actionis in taalen [sic] van Noord-Amerika." Verslagen en Mededeelingen der Koninklijke Akademie van Wetenschappen 5(2): 187-216.

Varma, D. 1935. La langue Braj (Dialecte de Mathura). Paris: Librairie d'Amérique et d'Orient Adrien-Maisonneuve.

Whitney, William. D. 1896. A Sanskrit grammar. Leipzig: Breitkopf and Härtel. 
Authors' addresses:

Saartje Verbeke

Research Foundation - Flanders (FWO)/Ghent University

Blandijnberg 2

B-90oo Ghent

Belgium

saartje.verbeke@ugent.be

Ludovic De Cuypere

Research Foundation - Flanders (FWO)/Ghent University

Blandijnberg 2

B-900o Ghent

Belgium

ludovic.decuypere@ugent.be 
